\title{
Capabilities and Gaps Assessments of Urban Air Quality Manage- ment in Uganda
}

\author{
Amin Tamale Kiggundu
}

Received: 3001 2015 / Accepted: 2002 2015 / Published online: 30062015

(c) 2015 Faculty of Geography UGM and The Indonesian Geographers Association

\begin{abstract}
Today, large cities across the globe are facing a pervasive problem of air pollution. The purpose of this study is to assess the capabilities and gaps in urban air quality management in Uganda as well as proposing strategies for curbing air pollution. This study applied face to face interviews, targeting key informants such as the environmental experts, urbanization researchers and officials from the National Environment Management Authority (NEMA). Results show that rapid motorization, continued dependence on fossil fuels, open waste burning, biomass burning, industrialization, bushfires and urbanization are the key causes of air pollution in Uganda. To reduce air pollution and improve urban air quality it is critical to promote non-motorised mass transport, increase electricity access, regulate open waste burning, establish laboratories, strengthen local research and training capacity, promote collaborations, introduce more fuel efficient vehicles and periodic vehicle inspection and carry out public awareness campaigns about air pollution.
\end{abstract}

Keywords: air pollution, urban air quality, Uganda, air quality management

\begin{abstract}
Abstrak Saat ini, kota-kota besar di seluruh dunia menghadapi masalah serius dari pencemaran udara. Tujuan dari penelitian ini adalah untuk mengkaji kemampuan dan celah dalam pengelolaan kualitas udara perkotaan di Uganda serta mengusulkan strategi untuk mengendalikan pencemaran udara tersebut. Penelitian ini dilakukan dengan menggunakan metode wawancara tatap muka, dengan menargetkan informan kunci seperti ahli lingkungan, peneliti urbanisasi dan pejabat dari the National Environment Management Authority (NEMA). Hasil penelitian menunjukkan bahwa motorisasi yang pesat, ketergantungan pada bahan bakar fosil yang terus-menerus, pembakaran sampah di tempat terbuka, pembakaran biomassa, industrialisasi, kebakaran hutan dan semak, dan urbanisasi adalah penyebab utama pencemaran udara di Uganda. Untuk mengurangi polusi udara dan meningkatkan kualitas udara perkotaan di Uganda, sangat penting untuk mempromosikan transportasi massal tak bermotor, meningkatkan akses listrik ke rumah-rumah, meregulasi pembakaran sampah di tempat terbuka, membangun laboratorium yang lengkap untuk menguji dan menganalisis sampel, memperkuat penelitian lokal dan pelatihan kapasitas tentang udara polusi, mempromosikan kolaborasi regional dan internasional tentang pencemaran udara, memperkenalkan kendaraan yang lebih efisien bahan bakarnya, secara berkala melakukan pemeriksaan kendaraan dan melaksanakan kampanye kesadaran masyarakat tentang pencemaran udara.
\end{abstract}

Kata kunci: pencemaran udara, kualitas udara perkotaan, Uganda, pengelolaan kualitas air

\section{Introduction}

Large cities across the globe are today facing a pervasive and insuperable problem of air pollution. According to the 2014 World Health Organisation Report, in 2012 about 3.7 million premature deaths occurred across the globe due to exposure to particulate matter of 10 microns or less in diameter (PM10). Besides, the recent increase in cases of upper respiratory tract infections (URTI) is due in part to the deteriorating air quality in most large towns and cities.

Studies also show that urban outdoor air pollution is responsible for an estimated 75,500 premature deaths each year in Africa and 49,100 in the Sub Saharan Africa (SSA) [World Health Organisation, 2007]. According to Haq and Schwela [2012] there is evidence linking

Amin Tamale Kiggundu

Department of Architecture and Physical Planning

School of Built Environment College of Engineering Design Art \&

Technology (CEDAT), Makerere University, Kampala, Uganda

Email: akiggundu@cedat.mak.ac.ug aircraft noise to high blood pressure.

Domestically, about 2,500 people with asthma were admitted in 2009/10 at Mulago National Referral Hospital. The prevalence of Asthma among children aged 8-13 years in Uganda is estimated at 26 percent. By contrast, it is just 10 percent among children of the same age in South Africa. Also, according to the 2010 NEMA Report, in Uganda, lower and upper respiratory tract infections account for more than 37 percent of the national disease burden.

Highlighted in the 2010 NEMA Report also is the continued emission of dioxins particularly from scrap metal processing factories that are located in big towns such as Kampala. Scrap metal processing is normally undertaken at very high temperatures, leading to the release of the above persistent organic compounds (POPs). Open waste burning in the major towns is also a key source of dioxins in Uganda.

Previous studies on urban growth and development 
in Uganda have also tended to ignore air pollution as a key issue that need to be investigated and explored with the aim of establishing a more optimal solution and improving air quality in various local towns and cities. This paper aims to assess and understand the capabilities and gaps in urban air quality management in Uganda. The paper is divided into various sections including the background, specific objectives, applied research method as well as key findings and discussion. Following the above sections is the discussion on existing gaps and capabilities as well as strategies for improving air quality management in Uganda. Last but not least is the conclusion.

The overall objective of the study is to assess the existing capabilities and gaps in managing urban air quality in Uganda. Specifically the study aimed to achieve the following objectives:

a) Evaluate the capabilities and gaps in urban air quality management in Uganda; and

b) Explore ways for local, regional and international cooperation in addressing urban air pollution

c) Propose strategies for improved air quality management and curbing air pollution.

\section{The Methods}

To achieve its intended goals and objectives, the study was undertaken using several research methods. Among them is the face -to- face interviews targeting key informants such as the NEMA officials, urbanisation researchers, municipal officials as well as local environmental specialists.

Existing literature in form official documents and reports, journal articles and text books was also reviewed to establish and expose the existing gaps and capabilities in managing urban air pollution.

\section{Result and Discussion}

Among the main drivers of air pollution in Uganda are transport, open waste burning, biomass energy for domestic use (cooking and lighting), bush fires, mining, industrialization as well as rapid urbanization. According to the National Environment Management Authority (NEMA), 75\% of air pollution in Uganda is due to transport-related activities.

Among pollutants of the greatest concern in Uganda are: sulphur dioxide (SO2), carbon monoxide $(\mathrm{CO})$, lead $(\mathrm{Pb})$, nitrogen oxides (NOx), volatile organic compounds, persistent organic compounds (POPS) and suspended particulate matter (SPM). Secondary pollutants formed from these include smog, ground level ozone and peroxyacetyl nitrate. The major effects of secondary pollutants include poor visibility, soil and soil water acidification in soils and streams, and acid rain.

About $75 \%$ of air pollution in Uganda is due to transport-related activities. Due to rapid economic growth as well as rising incomes, many Ugandans have been able to buy and use private vehicles. Also according to Uganda Bureau of Statistics (UBos), in 2008 there was a $30 \%$ increase in motor vehicle registration.

Uganda's current motor vehicle fleet is also estimated at 800,000 and over $70 \%$ of these vehicles are registered in Kampala. Between 1992 and 2004, the number of registered motor vehicles in Uganda increased from 53,000 to 247,000 [Mukwaya, 2007; Bateebe, 2011].

Motor vehicles in Uganda are widely regarded as status symbols as well as a sign of individual wealth and success [Mukwaya, 2007]. Private cars have also become more popular than public transport in part because they offer a door to door service and provide privacy. Cars are also a reliable mode of transport.

Daily vehicle dependence according Mukwaya [2007] increased from $67 \%$ in 2001 to $84 \%$ in 2004 . Most of the vehicles used in Uganda are second hand vehicles imported from mainly Asia and Europe.

Presently, there are no regulations with regard to the age of motor vehicles and the majority of imported vehicles in the country are not fitted with catalytic converters that reduce carbon emissions [Bateebe, 2011].

Increased dependence on fossil fuels such as petrol and diesel is also another key cause of air pollution in Uganda. Over the past decade the amount of fuel consumed by transport has increased substantially. Between 1991 and 2002, motor vehicle fuel sales increased from 202,184 cubic metres to 398,899 cubic metre [Mukwaya, 2007; Mukwaya, 2011; Bateebe, 2011].

According to Bateebe [2011] diesel and petrol are among the most consumed fuel products in Uganda. Besides, all the petrol and $80 \%$ of the diesel are used in the transport sector, which is responsible for over $75 \%$ of carbon emissions in the country. In 2009, diesel accounted for $60 \%$ of all the fuel sales in Uganda while petrol which is solely consumed by vehicles accounted for $26 \%$.

As earlier noted, most Ugandans depend on biomass energy for cooking and lighting. This is largely due to poor connectivity to the electricity grid as well as the ever increasing cost of power. Available statistics show that over $92 \%$ of the households in Uganda do not have access to electricity and often use fire wood and charcoal for cooking [NEMA, 2010]. It is widely recognised that the use of fire wood and charcoal for cooking is the main cause and source of hazardous pollutants including suspended particulate matter, carbon monoxide, nitrogen dioxide and other harmful gases.

There are also cases where uncollected garbage in the major urban centres is burnt openly by the urban residents in breach of the existing environmental laws as well as city planning ordinances. This is also a prevalent where the enforcement of the urban laws is poor and lacking.

Leaded fuels are still being used in Uganda by 


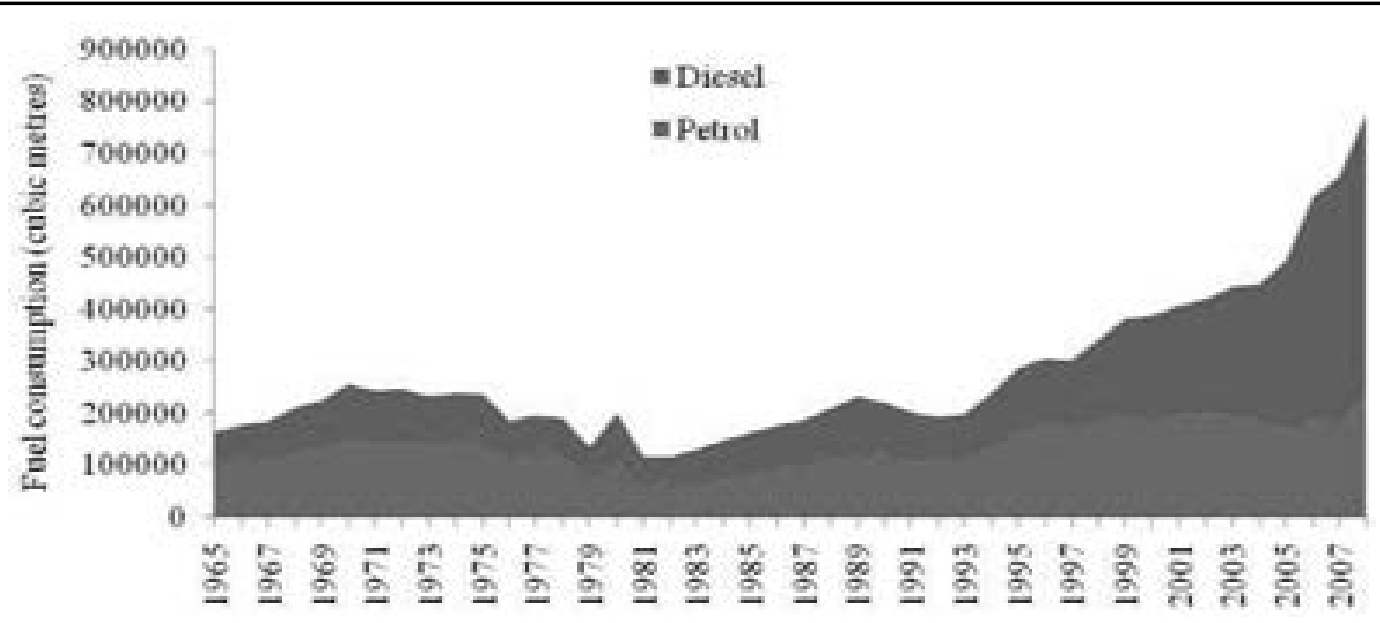

Figure 1. Fuel consumption in Uganda, 1965 - 2007 (Source: Mukwaya , 2011)

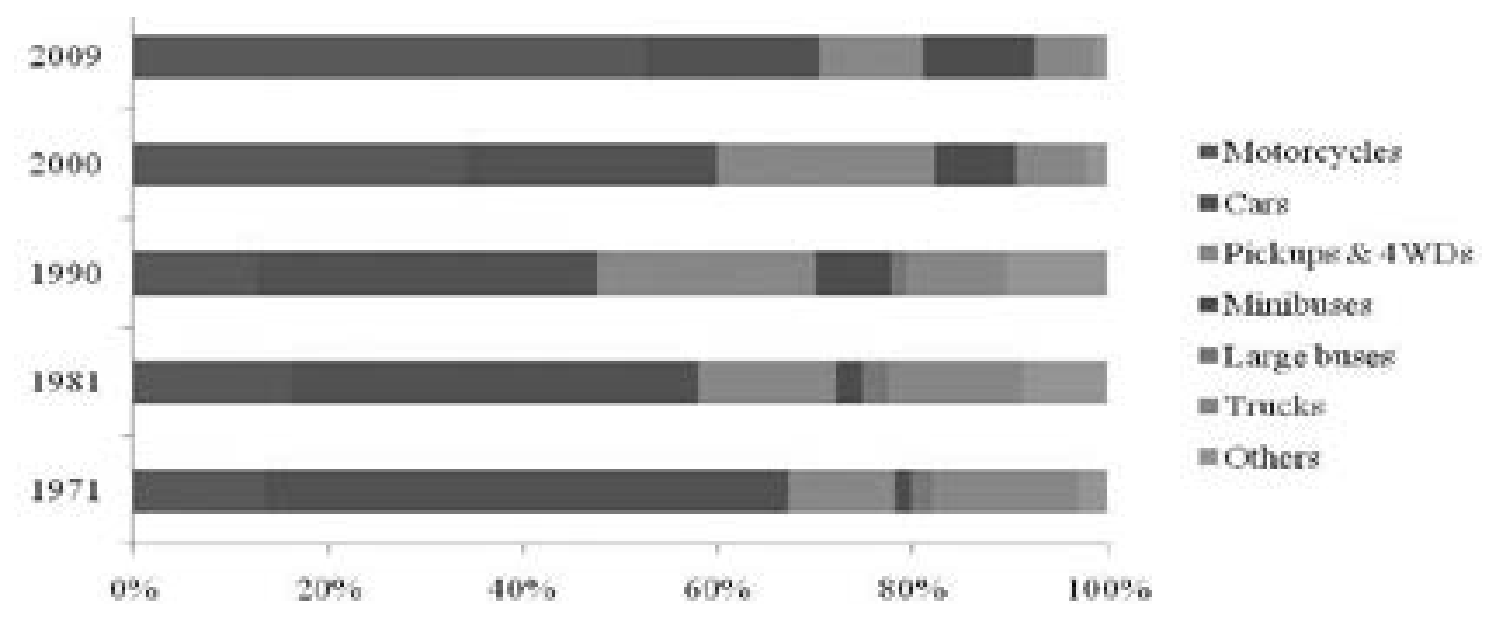

Figure 2. Vehicle composition by percentage 1971-2008

Source: Uganda Bureau of Statistics (UBos) \& Mukwaya (2011)

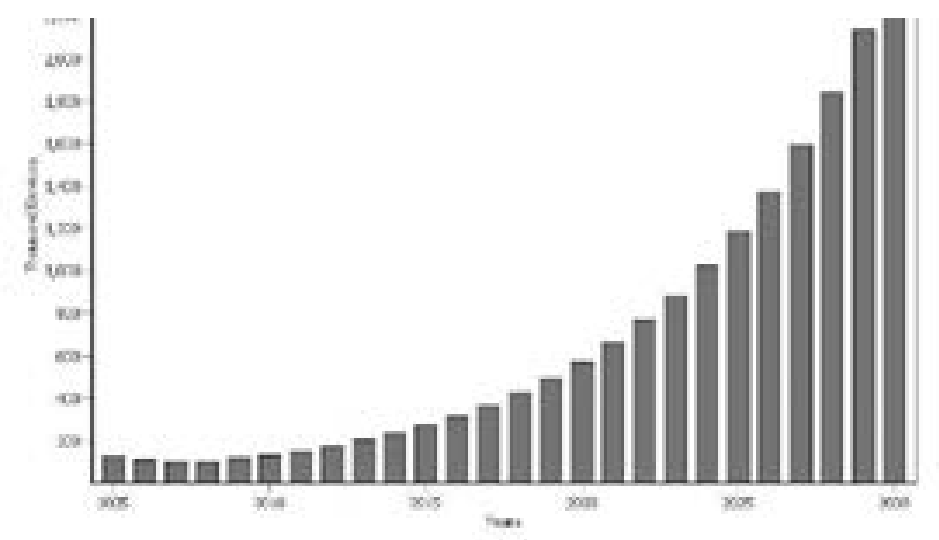

Figure 3. Automobile projections in Uganda from 2005 to 2030

motorists, contrary to the 2001 Dakar declaration and the 1995 World Health Organisation (WHO) recommendation that the use of additives in motor vehicles be phased out by 2005. Current standards by the Uganda National Bureau of Standards on leaded fuels are lead petrol levels should not be more than 0.05 $-0.4 \mathrm{~g} / \mathrm{l}$. There are however, signs that more fuel stations especially in the major towns are beginning to embrace the idea of selling unleaded fuels, which is a good policy in managing air quality and reducing air pollution.

Introduced in 1994, the National Environment Policy was the first environmental legislation to be made in Uganda. The key objectives of this policy is to collect, analyse, store and disseminate reliable 
information relating to environmental management issues in the country.

Following the National Environment Policy was the National Environmental Act Cap 153, which was introduced in 1995. Under this Act several institutions and governance structures such as the National Environment Management Authority (NEMA) and district environmental committees were established with a clear mandate of protecting the environment.

NEMA is required to make emission standards for various sources and make guidelines for air pollution control for both mobile and stationary sources. NEMA is also mandated under Section 28 of the Act to make standards for the control of noise and vibration pollution.

The above two environmental legislations are further reinforced by Articles 39 and 41 of the Constitution of Uganda. Article 39 provides for the right to a clean and healthy environment, while Article 41 provides for the right of access to information. Due to the growing public concern about the urban air pollution, a draft of the air quality standards and regulations was developed and released in 2005 by the National Environment Management Authority
(NEMA).

Emission standards for vehicles under the proposed NEMA air quality standards and regulations are as stated in Table 1 below. In addition, the standards for Uganda were developed for heavy duty diesel powered vehicles, diesel passenger cars, petrol passenger cars and petrol gasoline light trucks.

With support from the World Bank, the National Environmental Management Authority Laboratory was established in 2005. Although not fully equipped, NEMA laboratory is a crucial national asset used in protecting the environment in Uganda. Environment inspectors from NEMA laboratory often use noise meters to monitor noise pollution generated by bars, dancing halls and industries especially in Kampala.

Key sections of the Public Health Act 1964, the National Physical Planning Act 2010 as well as the Mining Act 2003 have also been used to protect the environment and improve air quality (Table 2). Under the Mining Act 2003 for example, mining companies are required to take necessary steps to 'ensure the prevention and minimimalization of pollution of the environment in accordance with the standards and guidelines prescribed under the National Environment

Table 1. Draft Emission Standards for Automobiles in Uganda

\begin{tabular}{llllll}
\hline Vehicle Category & \multicolumn{5}{c}{ Standard Applicable } \\
\hline & NOx & CO & PM & HC & VOCs \\
\hline Heavy duty diesel powered $(\mathrm{g} / \mathrm{kWh})$ & 7.0 & 4.5 & 0.15 & 1.23 & \\
Diesel Passenger Cars $(\mathrm{g} / \mathrm{km})$ & 1.25 & 4.2 & 0.08 & & \\
Petrol/gasoline passenger cars $(\mathrm{g} / \mathrm{km})$ & 0.08 & 1.2 & & 0.10 & \\
Diesel light duty trucks $(\mathrm{g} / \mathrm{km})$ & 0.38 & 2.6 & 0.06 & 0.19 & 0.19 \\
Petrol gasoline light trucks $(\mathrm{g} / \mathrm{km})$ & 0.6 & 2.1 & & 0.3 & \\
\hline
\end{tabular}

a. Heavy vehicles include good vehicles and buses (exceeding 3.5 metric tons) and trains; b. Light duty vehicles include cars and light trucks (less than 3.5 metric tons)

Table 2. Proposed Ambient air quality emission standards for Uganda and WHO

\begin{tabular}{llll}
\hline Pollutants & Time of average & $\begin{array}{l}\text { Draft Ugandan Ambient Air } \\
\text { Quality Standards (ppm) }\end{array}$ & $\begin{array}{l}\text { WHO Ambient Air Quality } \\
\text { Standards (ppm) }\end{array}$ \\
\hline Sulphur dioxide (SO2) & Annual & & 0.0076 \\
& $\begin{array}{l}24 \text { hour } \\
1 \text { hour }\end{array}$ & 0.15 & 0.19 \\
& 10 mins & & 0.022 \\
Nitrogen dioxide (NO2) & Annual & 0.1 & 0.111 \\
& 1 hour & & 20 \\
Particulate Matter (PM10) & Annual & & 50 \\
& 24 hour & 300 & 10 \\
Carbon monoxide & 1 hour & & - \\
Hydro carbons & 8 hour & 9 & - \\
\hline
\end{tabular}


Statute 1995, statute No.4 of 1995'. In addition, mining companies are required under the same Act to carry out an environmental impact assessment and annual environmental audits.

Due to the recent surge in the number of imported second hand vehicles, a new scheme code-named preshipment vehicle inspection scheme was introduced in the early 2010 by the Ministry of Trade and Industry as a strategy to prevent old vehicles from being imported into the country.

The management of urban air quality has become difficult because the majority of vehicles imported in the country are old vehicles that has not been equipped with emission control. Most vehicles used in Uganda are also poorly maintained. Poor maintenance of motor vehicles as highlighted by Bateebe [2011] and Mukwaya [2011] contributes to the higher emission in all classes of vehicle.

Continued use of polluting fuels is another major challenge faced in managing air quality in Uganda. There are cases where major fuel suppliers in Uganda have been apprehended by the Uganda National Bureau of Standards because of selling poor quality fuel. Most of these cases involve suppliers mixing paraffin with petrol.

Recognised also is the lack of a clear strategy to promote biofuels. Under the national energy policy [2002] it is proposed that biofuels such as ethanol be introduced as a strategy to reduce air pollution. However, not many start-up plantations of biofuels have been established in the country.

Nonetheless, biofuel production is likely to impact negatively on food production as more arable land will be earmarked for biofuel-related plantations in the country [NEMA, 2010].

Poor connectivity to the electricity grid which has resulted into dependence on biomass energy for cooking and lighting among households is also widely recognised as a key challenge faced in improving air quality. Indoor cooking with fire wood and charcoal has led to exposure of particulate matter to women and children.

There is an apparent lack of integration and mainstreaming of air quality issues in various national development plans. As elsewhere in the developing world, planning in Uganda is still based on a sectoral approach that allows development programmes and projects such as roads, power dams and housing to be implemented separately.

Interviews conducted with key informants from the National Environment Management Authority (NEMA) and Makerere University revealed that contrary to the Dakar declaration of 2001 and 1995 World Health Organisation (WHO) recommendation, motorists in Uganda still use leaded fuels. Also critical is the lack of the required regulatory framework such as approved air quality standards and regulations as well as the failure by NEMA to enforce the existing laws such as the Public Health Act, 1964 as well as the mining act 2003.

In the absence of a fully-fledged air quality management (AQM) system, key environmental issues such as air pollution continue to be addressed in an ad hoc fashion [Mukwaya, 2007; Bateebe, 2011]. Also missing in Uganda's air quality management (AQM) system is the required monitoring equipment as well as the lack of stakeholder participation including the mass media.

Unlike South Africa, Uganda lack well established urban air quality monitoring stations as well as local research networks focusing on air pollution. There are also no specific training programmes on air pollution taught at local Universities.

A further issue relates to the failure of involving various stakeholders in urban air quality management programmes. A study carried out by Bateebe [2011] found that $95 \%$ of the 40 minibus taxi operators interviewed in Kampala were not aware of the environmental damage caused by their poorly maintained vehicles. The study also revealed that the minibus operators were only concerned about making money to fend for their families. This obviously points to the lack of stakeholder participation as well as low levels of public awareness about the problem of air pollution in Uganda.

Highlighted also by the respondents is the lack of emission inventories for all sources. Hag and Schwela [2012] argue that without these inventories, it is practically impossible to apply dispersion modelling.

Governments across the globe have a responsibility to formulate policies and introduce required legislations for controlling air pollution. However, rarely have developing country governments especially in Sub Saharan Africa (SSA) introduced all the necessary laws to control both air and noise pollution (Table 3).

A closer look at the existing legal regime in selected SSA countries show that all countries have to some extent formulated policies and made laws to control urban air pollution. Among the selected SSA countries, only South Africa has approved air quality standards as well as sound pressure standards. The rest (Tanzania, Uganda, Zambia, Zimbabwe and Mozambique) lack the required standards for controlling air pollution. SSA countries outside South Africa also lack in noise management plans.

Without approved air quality standards, it is difficult to determine compliance as well as to punish those whom breaching the law. It is further difficult to prevent a continuous increase in air pollution. According to Haq and Schwela [2012] 'noise regulatory standards can set the reference point for emission control and abatement policies at the national, regional or municipal levels, and therefore can strongly influence the implementation of noise control policies.

Several legislative gap exists in the management of air quality in Uganda. Among them is the lack of a 
specific legislation focusing on controlling air pollution and promoting clean air programmes. Most of the existing environmental laws are general laws introduced to assist in managing the environment as a whole.

It is also worth noting that the existing legal regime for managing urban air quality in Uganda is fragmented and scattered in various legislations such as the Mining Act 2003, the National Environment Act 1995, the National Physical Planning Act 2010 as well as the Public Health Act 1964.Without these standards it is virtually impossible to determine compliance and punishment for those who breaching the law.

A pre-shipment inspection scheme for imported vehicles introduced by the Ministry of Trade and Industry in the early 2010 to prevent very old vehicles from entering Uganda also failed to achieve its intended goal in part because of strong opposition from the car lobby.

Local car importers argued that the scheme contributed to delay transactions, increased the cost of doing business and created avenues for corruption. Due to the fear to lose tax revenue government was forced to suspend the scheme in September 2010.

Recognised also is that there are no specific regulations for controlling dust as well as indoor air pollution in Uganda.

Most crucially, the proposed emission standards and regulations for Uganda were developed basing on the standards of developed countries. While the introduction of developed country standards may not be a bad idea, the institutional capacity required to enforce them is largely lacking in Uganda.

There is currently no known University in Uganda offering specific training programmes on air quality management. Most of the training programmes offered are general programmes focusing on environmental management (Table 4).

Even the short courses that were recently introduced at Makerere University on climate change mitigation are largely theoretical and do not provide the learners

Table 3. Legislation, policies, strategies and programmes on air pollution in selected SSA countries

\begin{tabular}{|c|c|c|c|c|c|c|c|c|}
\hline Country & $\begin{array}{l}\text { Environ-men- } \\
\text { tal Pro-tection } \\
\text { Leg-islation }\end{array}$ & Year & $\begin{array}{l}\text { Major } \\
\text { Responsi-ble } \\
\text { Au-thorities }\end{array}$ & $\begin{array}{l}\text { Poli-cies/Strategies/ } \\
\text { Programme }\end{array}$ & $\begin{array}{l}\text { Emission } \\
\text { Standards }\end{array}$ & $\begin{array}{l}\text { Sound } \\
\text { Pres-sure } \\
\text { Stand-ar- } \\
\text { ds }\end{array}$ & $\begin{array}{l}\text { Noise } \\
\text { Impact } \\
\text { Assess- } \\
\text { ment }\end{array}$ & $\begin{array}{l}\text { Noise } \\
\text { Man-age- } \\
\text { ment Plan }\end{array}$ \\
\hline Uganda & $\begin{array}{l}\text { National } \\
\text { Environment } \\
\text { Act Cap } 153\end{array}$ & 1995 & $\begin{array}{l}\text { National En- } \\
\text { viron-ment } \\
\text { Man-age- } \\
\text { ment Author- } \\
\text { ity }\end{array}$ & $\begin{array}{l}\text { National Envi-ron- } \\
\text { ment Man-agement } \\
\text { Policy (1994); the } \\
\text { na-tional envi- } \\
\text { ron-ment action } \\
\text { plan for Uganda } \\
\text { (1995) }\end{array}$ & $\begin{array}{l}\text { Being } \\
\text { Developed } \\
\text { (Draft is } \\
\text { available) }\end{array}$ & No & No & No \\
\hline $\begin{array}{l}\text { Tan- } \\
\text { za-nia }\end{array}$ & Constitution & 1998 & $\begin{array}{l}\text { Office of the } \\
\text { Vice Presi- } \\
\text { dent }\end{array}$ & $\begin{array}{l}\text { National Envi-ron- } \\
\text { mental Policy }\end{array}$ & No & No & No & No \\
\hline Zambia & $\begin{array}{l}\text { Environ-men- } \\
\text { tal Pro-tection } \\
\text { and Pollution } \\
\text { Control Act }\end{array}$ & 1990 & $\begin{array}{l}\text { Envi- } \\
\text { ron-mental } \\
\text { Council of } \\
\text { Zambia }\end{array}$ & $\begin{array}{l}\text { National Con-serva- } \\
\text { tion Strate-gy }\end{array}$ & $\begin{array}{l}\text { Being De- } \\
\text { veloped }\end{array}$ & $\begin{array}{l}\text { Being } \\
\text { De-vel- } \\
\text { oped }\end{array}$ & No & No \\
\hline $\begin{array}{l}\text { Zim- } \\
\text { ba-bwe }\end{array}$ & $\begin{array}{l}\text { Environment } \\
\text { Management } \\
\text { Act }\end{array}$ & 2002 & $\begin{array}{l}\text { Envi- } \\
\text { ron-mental } \\
\text { Man- } \\
\text { age-ment } \\
\text { Agency }\end{array}$ & $\begin{array}{l}\text { Draft National Envi- } \\
\text { ronmental Policy }\end{array}$ & No & No & No & No \\
\hline $\begin{array}{l}\text { South } \\
\text { Africa }\end{array}$ & Constitution & 1996 & $\begin{array}{l}\text { Depart-ment } \\
\text { of Envi- } \\
\text { ron-mental } \\
\text { Affairs and } \\
\text { Tourism } \\
\text { (DEAT) }\end{array}$ & $\begin{array}{l}\text { Environmental } \\
\text { Management Policy }\end{array}$ & Yes & Yes & Yes & Yes \\
\hline $\begin{array}{l}\text { Mozam- } \\
\text { bique }\end{array}$ & Constitution & 2004 & $\begin{array}{l}\text { Ministerio } \\
\text { para a Co- } \\
\text { or-denacao } \\
\text { da Accao } \\
\text { Ambiental } \\
\text { (MICOA) }\end{array}$ & No & $\mathrm{NO}$ & $\mathrm{NO}$ & $\mathrm{NO}$ & $\mathrm{NO}$ \\
\hline
\end{tabular}


Table 4. Key Gaps and Capabilities in Air Quality Management in Uganda

\begin{tabular}{lrll}
\hline \multicolumn{2}{l}{ Identified Gaps } & Comments & General Progress \\
\hline Lack of & approved & There are no gazetted emission standards and & A draft of emission standards and \\
emis-sion & standards & regulations and it is difficult to determine com- & regulationshasbeendevelopedbythe \\
and & regu-lations & pliance and punish those violating the law. Also & National Environment Management \\
& & some provisions of the NEMA Act 1995, Pub- & Authority (NEMA). Legislation on \\
& & lic Health Act 1964, the Mining Act 2003 and air quality is incomplete. There is \\
the National Phys-ical Planning Act 2010 are & no specific air quality policy or Act
\end{tabular}

Emissions from biomass burning not regulated

Existing legal regime is fragmented and scattered in various national legis-lations

Lack of specific dust control regulations

Lack of a feasible strategy to address the issue of open waste burning

Lack of specific training programmes on air pollu-tion

Land use and transport planning programmes rarely consider the issue of air pollution used by NEMA to protect the envi-ronment. Uganda is also a signatory to the Stockholm Conven-tion on Persistent Organic Pollutants and the Minamata Con-vention on Mercury.

Over $90 \%$ of households in Uganda use biomass energy for cooking and lighting. Access to electricity is still limited, only (8\%) of all households in the country. Most people are not aware of the problem of the emissions generated by biomass burning. Indoor cooking with fire wood and charcoal has led to high exposure of particulate matter to women and children in Uganda

Existing legal regime for managing air quality is fragmented and scattered in various legislations such as the NEMA Act 1995, Mining Act 2003, National Physical Planning Act 2010 as well as the Public Health Act 1964

Given that most roads in Uganda are not tarred or tarmacked, it is important that mechanisms are put in place to regulate dust

Open waste burning is common in large towns where the ur-ban authoritylack both the institutional and financial capacity to collect and dispose of solid waste. The uncontrolled burning of solid waste creates smoke. Open waste burning is also a major source of dioxin in Uganda.

There are various training programmes offered at various local Universities focusing on environmental management in general and climate change in particular. Most of these training pro-grammes are theoretical and do not provide the trainees practi-cal skills in air quality sampling and analysis.

Physical planning regulations only focus on the environmental impact assessment and do not address the issue of environ-mental audits
Better cooking stoves have been introduced. However, the regulation of indoor air pollution is still minimum.

The laws to protect the environment in general are available but there is no specific clean air Act

Lack of approved stand-ards and regulations for air quality monitoring including dust Inadequate response from the municipal authority to the problem. There is need to provide more financial resources to the urban authorities for managing waste, intro-duce bye laws and en-courage the urban resi-dents to participate in addressing the challenge Training programmes offered by local Universi-ties are generally focus-ing on environmental management and climate change. There is need for specific training pro-grammes on air pollution with the aim to create a critical mass of air pollu-tion experts There is need to integrate air quality management in land use and transport planning 
and trainees practical skills in sampling for gaseous and particulate pollutants as well as air quality monitoring.

Some local human resource capacity comprising of mainly environmental experts trained from abroad however, exists. Most of these experts work in private engineering consultant firms such as Water Air Earth.

The local capacity to carry out research on air pollution is somewhat inadequate and lacking. No permanent monitoring sites/stations and studies on air quality are undertaking ad hoc fashion. Existing laboratories are not fully equipped to enable researchers to carry out meaningful scientific research on air pollution in the country.

Research on air pollution has also been affected by the absence of well-established networks for collaborative research at both national and regional levels.

Uganda also lack an emission inventory as well as continuous air pollution monitoring and control system. Besides, there are no comprehensive studies that have been carried out to establish the exact impact of air pollution on the economy as well as health of the people.

Most institutions and agencies mandated to regulate and manage air quality in Uganda are relatively new. For example, the National Environment Management Authority (NEMA) was established after the introduction of the National Environment Act in 1995. The capacity of these institutions to regulate air pollution and enforce the existing laws is largely lacking. This is because of inadequate funding as well as the failure to recruit enough skilled manpower. The lead agencies such as NEMA also lack fully equipped laboratories to test and analysis samples. Above all, there are no air quality strategic plans as well as established stations for regular air quality monitoring for both the central as well as municipal governments.

Several opportunities for cooperation at national, regional and global levels in air quality management exist. Globally, Uganda and other EAC (East African Community) countries are parties to various multilateral environmental agreements including the United Nations Framework convention on Climate Change.

In addition the 2001 Dakar Declaration on phasing out leaded gasoline in Sub Saharan Africa countries constitutes a big opportunity for cooperation at international level. Under this Declaration, $25 \mathrm{Sub}$ Saharan Africa (SSA) countries including Uganda agreed to phase out leaded gasoline in all SSA countries by 2005 at the least.

Uganda and other African countries are also involved in Vienna Convention on trans-boundary air pollution.

Through the Minamata Convention implementation plan, Uganda could participate in the development of a mercury emissions inventory and the assessment of mercury emissions. Also important is the existence of several international protocols such as Kyoto and Montreal protocols.

Several international research networks such as the Test Network and APINA could be used to further cooperation and collaboration on air pollution control and regulation especially at national and regional levels.

International funding programmes such as GEF (Global Environment Facility) could also be used to finance air quality management projects at both national and regional levels.

Based on the findings of the study as well as the gaps and capabilities highlighted above, it is recommended that:

For the lead agencies such as the National Environment Management Authority (NEMA) to be able to control air pollution and determine compliance. It is critical that the air quality standards and regulations in Uganda are gazetted. It is further critical that the capacity of NEMA to enforce these standards is strengthened through the purchase of required equipment as well as the recruitment of enough skilled manpower.

Mass transport (trains, light rails, buses and trams) should provide direct and fast connections to key destinations such as urban centres, major employment centres as well as leisure zones. It is also critical that transit systems offer a reliable, affordable, frequent and accessible service. Bateebe [2011] asserts that a passenger standard vehicle (private cars) has $\mathrm{CO}$ emission rates ten times higher than those of an urban bus. So efforts must be made to improve transit efficiency, operations and competiveness especially in the major local towns and cities.

Strengthening the local research and training capacity on air pollution is a critical component of an effective air quality management system. This can be achieved through increasing staffing levels of the lead agencies such as NEMA, training of staff for enhanced air quality control as well as establishing fully equipped laboratories. It is also important that the air quality monitoring stations are established to allow regular monitoring and research on air pollution. Besides, efforts must be made to introduce specific training programmes on air pollution in various local Universities and other research institutions.

Open waste burning is a pervasive problem in many local urban centres and it is largely caused by poor waste management practices. To address this challenge, it is important that bye laws are introduced and strictly enforced by the urban authority especially at the periurban level. Also the urban residents, the private sector and other key stakeholders should be involved in the management of solid waste.

Tax rebates have been introduced in many developed countries such as Singapore as an incentive and a strategy to encourage consumers and investors to use cleaner technologies such as fuel efficient hybrid vehicles and as a means to reduce air pollution. In 
Uganda, this policy has not yet been introduced. So it is critical that tax rebates are introduced as a strategy to promote cleaner technologies and curb air pollution.

Continued dependence on biomass energy (especially fire wood and charcoal) for cooking and lighting among households in Uganda is a major cause of air pollution as well as respiratory diseases among women and children. While new and more efficient cooking stoves have in the recent years been introduced in Uganda, very little has been done to popularize them among the households across the country. It is also critical to increase access to electricity as well as other renewable energy sources such as solar energy. Campaigns should also be carried out to raise public awareness about the dangers associated with the continued dependence on biomass energy as the main source of energy for cooking and lighting in the country.

Walking and cycling are widely regarded as sustainable modes of transport because they produce zero carbon emissions. Also in developing country towns and cities where walking is still popular among commuters (for example in Kampala, over $50 \%$ of the commuters walk each day from home to their work stations and back), it is important that a conducive environment for the use of the two modes of transport is established. This can be achieved through: (a) providing cycling and walking infrastructure such as pedestrian paths and cycling lanes; (b) secure bike storage in cycle stands; (c) improve road safety by providing pedestrian walkways, footbridges and lighting; (d) promote bike sharing schemes; and (e) improve walking and cycling facilities in schools, near shopping centres and neighbourhood areas.

Continued dependence on private vehicles is one of the major causes of air pollution in the developing country cities. Reduced car dependency can be achieved by the introduction of the following transport demand management measures: establishment of car free zones within the city centre, reducing on the supply of car parking spaces, restriction of car access at certain time of the day, providing park and ride facilities, introducing congestion charges as well as increasing both car and fuel taxes. It is further critical that public awareness campaigns are carried the problems caused by rapid motorisation as well as its impact on economic performance.

The hybrid vehicles are associated with a very low fuel consumption resulting in a great reduction in emissions. A study by John and Kurani [2010] on energy impacts of hybrid vehicles revealed that the use of Plug-in Hybrid Vehicles (PHEV) could halve gasoline use relative to conventional vehicles.

The use of fossil fuels such as petrol and diesel should be reduced. In addition government should adopt a more feasible strategy for promoting cleaner fuels such as liquefied petroleum gas (LPG), unleaded gasoline, ethanol as well as compressed natural gas (CNG). Incentives in form of tax rebates should also be introduced to allow a shift to cleaner fuels.

Regular and periodic vehicle inspection is important for controlling air pollution and safeguarding air quality. It is therefore recommended that a comprehensive motor vehicle pollution control program be designed to implement the proposed NEMA vehicle emission standards. The new program should also aim to control the age of motor vehicles as well as making it mandatory for all imported vehicles to be fitted with catalytic converters.

The participation of various stakeholders is critical because air pollution control requires behaviour change in consumption as well as individual travel. Programmes aimed at promoting cycling, walking and public transport cannot be successful without the involvement of the various stakeholders. The media is also critical in raising public awareness about air pollution and partnerships should be established with various local media organisations with the aim of educating the public.

Through APINA and other regional and international research networks a training programme on air quality monitoring should be introduced in Africa as a way of building local research capabilities and filling the existing training gaps.

\section{Conclusion}

The main objective of this research was to assess the existing gaps and capabilities in air quality management and make policy recommendations for Uganda. Highlighted in the study is that transport contributes about $75 \%$ of air pollution in Uganda.

Also the study identified various capacity gaps and capabilities such as: incomplete and fragmented legislation on air quality management, lack of a clear strategy for promoting cleaner fuels, continued dependence on biomass energy for cooking and lighting, prevalence of open waste burning, bush fires, lack of regular and periodic vehicle inspection and maintenance, lack of emission inventory, inadequate research and training capacity, lack of an integrated approach towards land use and investment planning, dependence on fossil fuels such as petrol and diesel, rapid motorisation, lack of control and restrictions on the age of vehicles used in Uganda as well as lack of operational air quality monitoring system.

The study also revealed that various stakeholders such as the mass media and local urban residents are rarely involved in the air quality management programmes. To reduce air pollution and improve air quality in Uganda, it is critical that the air quality standards are gazetted and approved by the government, integrate air pollution in the national development plans and existing planning system, introduce bye laws to regulate open waste burning in various towns, increase access to electricity and solar power among households, increase access to public transport among commuters, strengthen regional and international collaboration on 
air pollution, strengthen local research and training capacity on air pollution, adopt a more feasible strategy to promote fuel efficient vehicles, introduce a policy to control the age of imported vehicles, promote walking and cycling, and adopt an integrated approach towards land use and transportation planning.

\section{References}

Bateebe, I. P. (2011), Investigation of probable pollution from automobile exhaust gases in Kampala city, Uganda, Msc. Thesis, KTH School of Industrial Engineering and Management Energy Technology, Stockholm, Sweden.

Haq G. and Schwela, D. (2012), Transport and environment in Sub Saharan Africa, London: Stocholm environment institute, University of York.

John, A. and Kurani, K.S. (2010), Anticipating plug in hybrid vehicle energy impacts in profiles, Transport research data base available at www.elsevier.com/ locate.trd assessed 20/05/2010.

MEMD (2002), Ministry of Energy and Mineral Development, Uganda's Energy Policy, Ministry of Energy and Mineral Development, Kampala, Uganda.

Mukwaya, P.I (2007), Experiences and Milestones in carbon governance in Kampala city region: challenges of satisfying global concerns at the local level, Amsterdam Conference on the Human Dimensions of Global Environmental Change 24 -26 May 2007, Earth System Governance: Theories and Strategies for Sustainability.
Mukwaya, P.I (2011), Reducing the carbon footprint from transportation in growing cities: Application of city planning approaches in Kampala city, Uganda, PhD Thesis, Makerere University, Kampala, Uganda.

National Environment Management Authority (2005), Draft Air quality standards and regulations, Kampala: NEMA.

National Environment Management Authority (2007), State of Uganda's environment report 2007, Kampala: NEMA.

National Environment Management Authority (2010), State of Uganda's environment Report 2009/2010, Kampala: NEMA.

National Environment Management Authority (2008), State of Uganda's environment Report, 2008, Kampala: NEMA.

UNEP (2012), Cost and benefits of clean technologies for bus rapid transit (BRT), Nairobi: United Nations Environment Programme (UNEP).

Walsh, M. P. (2010), The Tehran transport emissions reduction project, Journal of Urban Technology, 6:1, 47-61. 